\title{
One Thing Leads to Another: Making Sense of East Asia's Repeated Tensions
}

Over the past decades, there have been a series of unresolved, iterated episodes of tension between the People's Republic of China (PRG) and other states in East Asia. These include the Japanese detainment of a Chinese fisherman in 2010, the standoff between ships from the PRC and Philippines at Scarborough Shoal in 2012, and the 2015 clash between the PRG and Vietnam over the PRG placement of an oilrig near the Paracel Islands. A series of unilateral actions in the region have also generated tensions, including the Japanese nationalization of the Senkaku/Diaoyu Islands in 2012, the PRC establishment of an Air Defense Identification Zone (ADIZ) over the East China Sea, and reclamation efforts in the SCS, most notably by the PRC. Why do these tensions seem so intractable? What effect does each episode of heightened tension have on subsequent stand offs?

One approach would be to examine these episodes as isolated events, after which business returns to normal. Indeed, a standard approach within many analyses is to treat each incident as a single data point, and then look for generalizable patterns in their eliciting circumstances or escalatory dynamics. Such an approach would ask: under what circumstances do we see incidents occurring that lead to tensions?

A second possibility would be view these incidents as indicators of some deeper type of political rivalry among the actors involved. That is, to treat these events as the manifestation of tensions, not a cause. Here the variable of interest is not the crises themselves, but the nature of the underlying relationship that gives birth to such events.

We suggest a third perspective, building on existing work on evolving rivalries, learning, and spiral models, but adding additional insights from more recent work on emotions within international relations. We believe that iterated, unresolved episodes of tension need to be viewed in an integrated fashion, whereby the previous event sets the context for the next. With each outbreak of tension, the political terrain shifts, and knowing how and where these shifts can occur may help illuminate subsequent risks. Specifically, we highlight mechanisms through which iterative episodes of tension can interact with known psychological dynamics to shape political attitudes, perceptions of new information, and the political incentives actors face. In doing so, we offer a cautionary warning to those who would assume that crises are resolved when tensions subside. And there is good reason to think that subsequent rounds of tensions are exacerbated by prior, unresolved episodes. Indeed, as we shall briefly discuss below, a pattern of repeated, unresolved conflicts set the stage for the outbreak of World War I. The question which interests us here, however, is to what extent do we see such dynamics at work in East Asia today? 
To illustrate the contemporary value of this approach, we look at the aftermath of episodes of tension within the context of the PRC's relations with Japan and the Philippines. The Philippines itself provides for an interesting contrast to Japan, as it does not share longstanding historical animosities with the PRC. While Vietnam is also an important case of iterative tensions in East Asia, we do not examine it given space constraints. We are agnostic as to who is at fault in any of these relationships. Our interest is in how iterated tensions within these relationships may make it more difficult to return to the baseline of pre-tension relations.

Before embarking, a word to definitions. The term "episodes of tension" describes incidents involving a clash of interests in a dispute that has the potential of militarization. Full-blown crises naturally fit this definition, but so too do unilateral actions that do not result in military crises - such as the Japanese nationalization of the Senkaku/Diaoyudao islands. By unresolved, we mean incidents where the immediate fear of militarization may subside, but no mutually agreed, lasting resolution emerges.

\section{Grises and Rivalries}

There are two dominant approaches to understanding crises or "incidents" involving tensions between states within international relations. The first takes such incidents as single events and focuses on initiating conditions, escalatory dynamics, and possible paths for resolution. The second approach views crises and flares of tension as symptomatic of deeper, underlying issues, be they broad-scale structural forces or dyadic rivalries. The problem with the both approaches are that they are unable to explain the effects of prior tensions on subsequent interactions, thereby generating the escalatory patterns we can observe in East Asia. We address each in turn.

Stein defines crises as involving "a threat to basic values, and awareness of a finite time for response, and a perception that there is a high probability of involvement in military hostilities." " The scholarly interest in crises needs little explanation: crises are moments where the implications of even seemingly minor decisions can mean the difference between war and peace.

A central tradition within the single-event approach to crises is the rationalist one. Beginning with Schelling, many rationalist approaches have sought to provide guidelines for how leaders should calibrate concessions and threats to preserve important values while minimizing the likelihood of war. ${ }^{2}$ Such work often treats crises as situations where the actors who succeed are those most capable of credibly threatening an adversary to incur harm in excess to the value of the disputed object or issue.

${ }^{1}$ Stein, "Crisis Behavior: Miscalculation, Escalation, and Inadvertent War," Robert A. Blackwell

Publishing,

<http://www.isacompendium.com/subscriber/tocnode.htmleid=g9781444336597_yr2013_chu nk_g97814443365975_ss 1-27>.

2 Schelling, The Strategy of Conflict (Cambridge: Harvard University Press, 1980); Arms and

Influence (New Haven, GT: Yale University Press, 1966). 
More recent work has sought to explain how crises can result in war even where both actors are rational. Pointing to the costliness of war, Fearon posits that rational actors with perfect information should prefer a deal that divides the target of contention (territory, political control, etc.) to reflect the likely outcome of a conflict without incurring its costs. ${ }^{3}$ Because the capabilities and resolve of an actor are private information, not fully knowable to an adversary, actors have the incentive to deceive to obtain a better deal. This in turn can lead to actors not knowing the real capabilities or resolve of their adversaries, and thus being unable to reach a war-averting deal. Rationalist scholars have suggested several ways to overcome this, including providing "hard" signals such as incurring large costs or running risks to demonstrate resolve, or tying one's hands by making public statements that create political penalties for backing down.

From either perspective, learning from earlier rounds of crises should have a calming effect on relations, de-intensifying subsequent rounds of differences, possibly even helping to prevent repetition. As Chan notes, "with each additional round of confrontation, shouldn't they be in a better position to resolve uncertainties about their counterparts' capabilities and intentions, thereby making it easier for them to reach a settlement? Having gained a better understanding of each other's capabilities and intentions after each successive crisis, they should be better able to avoid another one." ${ }^{4}$ Bluntly, a crisis should itself work to reveal capabilities or resolve; this in turn should solve the issues that generated the crisis in the first place. Repeated crises, in this view, should lead to a convergence of expectations, not increasing tensions. Recurrent cycles of intensifying conflict thus would seem puzzling.

There is another possible rationalist answer: the inability to commit. Namely, in situations where the balance of power is changing between actors, the actor with a growing advantage has the incentive to renege on previous commitments to receive a better settlement reflective of the new balance. ${ }^{5}$ This argument presents an important parameter within which crises may recur, but it does not account for the effect of crises on future conflict.

Apart from rationalist writings, a large body of work on crises exists within the political psychology and foreign policy analysis literatures. Classics include Allison's Essence of Decision or Janis and Mann's Decision Making. ${ }^{6}$ Allison, looking at the Cuban Missile crisis, makes the argument that bureaucratic and organizational factors played an important role in the outcome of that incident. Janis and Mann, in contrast, provide an extensive outline of various psychological dynamics at the individual and group levels that

${ }^{3}$ Fearon, "Rationalist Explanations for War," International Organization 49, no. 3 (1995);

"Domestic Political Audiences and the Escalation of International Disputes," American Political Science Reviere 88, no. 3 (1994).

${ }^{4}$ Chan, Enduring Rivalries in the Asia-Pacific (Cambridge University Press, 2013), 6.

${ }^{5}$ Fearon, "Rationalist Explanations for War."

${ }^{6}$ Allison, Essence of Decision: Explaining the Cuban Missile Crisis, (Boston: Little, Brown,1971); Janis and Mann, Decision Making: A Psychological Analysis of Conflict, Choice, and Commitment (Free Press, 1977). 
can shape how policymakers respond to conflict. ${ }^{7}$ These include satisficing (choosing options that are not optimal, but meet a minimum set of criteria); bolstering (inventing rationales to make one option more attractive than others); and groupthink (whereby group dynamics exacerbate tendencies towards biased decision-making).

In either case, the bureaucratic, organizational, or psychological processes at work can have a detrimental effect on decision-making. And the high-stakes and high-stress environment of crises makes them particularly significant. ${ }^{8}$ Both works have spawned massive subsequent bodies of research, ${ }^{9}$ and the point here is not to summarize the literature. Rather, it is to note that most of this literature is primarily interested in the decisions policymakers reach, not necessarily their aftermath. ${ }^{10}$ The various institutional or psychological factors are treated as given elements of the crisis making environment as opposed to being the function of previous crises, and the crises analyzed in this literature are generally detached from their larger historical context.

A further take on crises is more quantitative, asking what variables increase or decrease the likelihood of crises emerging and, subsequently, being resolved in a peaceful fashion. This is the approach behind the International Crisis Behavior (ICB) Project, for example, which has amassed a significant database of international crises, their triggering effects, associated contexts, and outcomes. ${ }^{11}$ Variables associated with the outbreak and escalation of crises include geographic proximity, regime type, and the age of the states involved. ${ }^{12}$ The ICB project indeed includes data on protracted conflict that allows the contextualization of specific crises within potentially larger series of unresolved conflicts between actors. Indeed, scholars have found that dyads involved in protracted conflict are more prone to violent escalation and war. As Brecher notes, a protracted conflict "generates more issues in dispute, for mistrust spills over to all domains of interaction. The result is that virtually any issue over which there is less than a total understanding becomes a source of friction, hostility, and mutual threat." 13 While Brecher's comments suggest an iterative escalatory process, the quantitative approach generally treats protracted crises as a contextual variable for predicting the likelihood of future crises, not an evolutionary dynamic itself needing explanation.

\footnotetext{
${ }^{7}$ Janis and Mann, Decision Making, 70.

${ }^{8}$ Holsti, "Crisis Decision Making," in Behavior, Society, and Nuclear War, ed. Tetlock, et al. (1989).

${ }^{9}$ For an overview, see: Stern, "Crisis Studies and Foreign Policy Analysis: Insights, Synergies, and Challenges," International Studies Review 5, no. 2 (2003); Boin, "Lessons from Crisis

Research," ibid.6, no. 1 (2004).

${ }_{10}$ One exception is Richard Ned Lebow, whose contribution will be discussed below: Lebow, Between Peace and War: The Nature of International Crisis (Johns Hopkins University Press Baltimore, 1981), 310-17.

11 See: International Crisis Behavior Project Homepage, University of Maryland, accessed 2 July 2014, at: http://www.cidcm.umd.edu/icb/

12 Brecher, "Crisis Escalation: Model and Findings," International Political Science Revieze 17, no. 2 (1996).

13 Ibid., 219.
} 
There exists, however, a second broad approach that views crises simply as symptoms of larger, underlying processes. This is the view many systemic explanations adopt. They do not predict specific conflicts, but the likelihood of conflicts given specific systemic configurations. Waltz's writings on the instability of multipolarity are possibly the most well known in this regard. ${ }^{14}$ Similarly, Mearsheimer's offensive realism, which suggests rising powers will seek to establish hegemony within their regions also predicts an increase in the amount of conflict with those that seek to hinder their efforts. ${ }^{15}$ Neither approach pays much attention to the effects of crises; nor, given their focus on the distribution of military power, should we expect this. Crises and other episodes of tension are a function of systemic factors; unless they result in a systemic war that alters the distribution of power, they play little role in altering the dynamics shaping their own emergence.

Possibly a more fruitful way for theorizing the consequences of crises is not to look at systemic factors, but rather dyadic ones. This is the approach of the structural literature on rivalries. We describe this literature as "structural" for it treats rivalries as statistically given elements of the dyadic structure in which conflict occurs. ${ }^{16}$ The structural rivalries literature is interested in the likelihood of war and crises, and hypothesizes a positive relationship to pre-existing rivalries. In earlier work, scholars adopted a measure of rivalry based on previous conflict very similar to that used by crisis scholars examining protracted conflict, namely the density of previous disputes. ${ }^{17}$ Goertz and Diehl, who employed this operationalization, found that "only a small percentage of all possible dyads account for a disproportionate amount of international conflict" and the "vast majority of disputes $(79 \%)$ take place in some rivalry context..."18

More recent operationalizations have sought a more fine-grained approach to determining international rivalries. Thompson, for example, looks at actual historical perceptions to code rivalries, including whether policymakers perceived the other side as a threat, enemy, and competitor. ${ }^{19}$ This work, too, finds a greater likelihood for rivalries to result in militarized crises and war. ${ }^{20}$

The findings of the structural rivalries literature are quite impressive, but much of the work treats rivalries as existing or not, as categories not processes. Granted, some authors distinguish between proto rivalries (where states have engaged in two to four militarized disputes, with no more than a ten-year break between disputes) and full-blown enduring

14 Waltz, Theory of International Politics, First ed. (New York: McGraw Hill, 1979).

${ }^{15}$ Mearsheimer, The Tragedy of Great Power Politics (New York: Norton, 2001).

${ }_{16}$ Maoz and Mor, Bound by Struggle: The Strategic Evolution of Enduring International

Rivalries (University of Michigan Press, 2002), 12.

17 Goertz and Diehl, "Enduring Rivalries: Theoretical Constructs and Empirical Patterns,"

International studies quarterly (1993).

18 "The Empirical Importance of Enduring Rivalries," International Interactions 18, no. 2 (1992): 158.

19 Thompson, "Identifying Rivals and Rivalries in World Politics," International Studies

Quarterly 45, no. 4 (2001).

20 Colaresi and Thompson, "Strategic Rivalries, Protracted Conflict, and Crisis Escalation,"

Journal of Peace Research 39, no. 3 (2002). 
ones (conflicts between the same two states that involve at least five militarized disputes in a period lasting at least ten years), ${ }^{21}$ but this is simply a multiplication of categories. The structural rivalries literature for the most part does not offer a story of the psychological dynamics emerging from recurrent tensions, dynamics whose intensity may increase with each iteration.

A last alternative is the non-rationalist, structural account of the logic of habit developed by constructivists, most prominently Ted Hopf. ${ }^{22}$ The persistent and unresolved tensions that constitute rivalries may, from this perspective, be a set of familiar behaviors and actions that states and their leaders settle into given repeated interactions that occur along broadly similar lines. Tensions are structural in the sense that they are embedded in the fundamental nature of a relationship. In some cases, the enduring tensions may even become an element of both actors' identities. ${ }^{23}$ But taking this view also poses difficulties for explaining change.

\section{Theorizing the Effects of Unresolved, Iterated Episodes of Tension}

The above approaches are useful for understanding how both immediate and more broadly structural variables shape the occurrence of iterated episodes of tension as well as the likely outbreak of war. But there are a variety of theoretical reasons to expect iterative, unresolved episodes of tension to have important effects on subsequent interactions beyond those outlined above. These insights come from the literature on evolutionary rivalries, ${ }^{24}$ older writings on learning after crises and applications of cognitive psychology to international relations, ${ }^{25}$ and more recent work concerning affect and emotion. ${ }^{26}$ In what follows, we seek to draw on and integrate the insights of these

${ }^{21}$ Goertz and Diehl, "The Empirical Importance of Enduring Rivalries."

22 Ted Hopf, "The Logic of Habit in International Relations," European Journal of International Relations 16, no. 4 (2010).

${ }^{23}$ Mitzen, Jennifer. "Ontological security in world politics: state identity and the security dilemma." European Journal of International Relations 12, no. 3 (2006): 341-370. ${ }_{24} \mathrm{Maoz}$ and Mor, Bound by Struggle: The Strategic Evolution of Enduring International Rivalries; Vasquez, The War Puzzle Revisited, vol. 110 (Cambridge University Press, 2009); Hensel, "An Evolutionary Approach to the Study of Interstate Rivalry," Conflict Management and Peace Science 17, no. 2 (1999).

${ }^{25}$ Jervis, Perception and Misperception in International Politics (Princeton, NJ: Princeton University Press, 1976); Lebow, Between Peace and War: The Nature of International Crisis; Leng, "When Will They Ever Learn? Coercive Bargaining in Recurrent Crises," Journal of Conflict Resolution 27, no. 3 (1983); Jervis, Lebow, and Stein, Psychology and Deterrence (Baltimore, MD: Johns Hopkins University Press, 1985).

${ }^{26}$ Saurette, "You Dissin Me? Humiliation and Post 9/11 Global Politics," Reviere of

International Studies 32, no. 3 (2006); Löwenheim and Heimann, "Revenge in International Politics," Security Studies 17(2008); Stein, "Psychological Dimensions of International Decision Making and Collective Behavior," (Toronto2011); Mercer, "Emotional Beliefs," International Organization 64, no. Winter (2010); McDermott, "The Feeling of Rationality: The Meaning of Neuroscientific Advances for Political Science," Perspectives on Politics 2, no. 4 (2004). 
diverse literatures by making several propositions concerning the possible effects of iterated, unresolved episodes of tension.

1) Iterated, unresolved episodes of tension can generate a propensity to react to the future behavior of counterparts as if it were provocative and hostile.

Iterated, unresolved episodes of tension can leave actors with a negative view of the other side. Where such episodes are resolved through solutions acceptable to both sides, they may simply fade into the past as misunderstandings or unfortunate incidents. Where unresolved, however, they can leave actors expecting their counterparts to act in a similar manner in the future, as no common understanding exists. Unresolved tensions leave behind the perception that each acted in a manner inimical to the other's interests. As these repeat, the result for states that have experienced a series of tensions is "an accumulation of hostility and grievances through their past history of conflict."27

This is significant, for it can shape interpretations of future behavior. As Jervis notes, it is difficult to make sense of the world without interpretive frameworks. ${ }^{28}$ These help us order and interpret incoming information, particularly when it is ambiguous. We all have theories of how the world works through which we assimilate and make sense of what we perceive. Hence, we are not surprised when the sun comes up, but expect some form of deception when we see a magic trick. Our pre-existing understandings of the world tell us what is plausible and what is not. But the problem with such understandings is that when sufficiently solidified they can also lock us into discounting evidence challenging our expectations, or assuming with confidence our interpretations of information which is ambiguous.

Rationalist approaches to international relations suggest we should update our beliefs in a Bayesian fashion. ${ }^{29}$ That is, we should adjust our certainty in our beliefs based on the confidence we have in new, disconfirming information. However, how we actually interpret incoming information is strongly shaped by pre-existing beliefs, and therefore the latter may be very difficult to alter. Indeed, much within international relations is ambiguous. Are increases in military spending a sign of revisionist intentions or simply the product of bureaucratic politics? Is a concession genuine gesture to improve relations or a deceptive move to get a state to lower its guard? How one falls on these questions often reflects how one already understands the world.

This is the phenomena of top-down processing: an existing framework is used to make sense of the world, and determines how we make sense of ambiguous information. And when actors are especially attached to a certain belief structure, they may even creatively reinterpret or seek to explain away seemingly unambiguous information that does not fit their expectations. Just as we may say to ourselves that an astonishing magic trick must

${ }^{27}$ Hensel, "An Evolutionary Approach to the Study of Interstate Rivalry," 186.

${ }^{28}$ Jervis, Perception and Misperception in International Politics, 117-202.

29 Morrow, Game Theory for Political Scientists (Princeton University Press, 1994). 
have a rational explanation, so too actors may discount disconfirming evidence with post hoc rationalizations.

Once a negative view of another actor is established, it may thus end up being very difficult to dislodge. As this negative view takes root, past behavior that would otherwise be viewed in neutral terms comes to be interpreted negatively, thus giving rise to even further episodes of tension. As Maoz and Mor write, "Accommodative statements and attitudes of the opponent tend to be viewed in a biased and suspicious manner, while hostile attitudes are seen as true reflections of the rival's intentions and attitudes." 30 Each new outbreak of tensions solidifies existing expectations, and a hostile belief structure can be come solidly entrenched.

All this is reinforced by what we now know about the roles of feelings and emotions. Episodes of tension, by their very nature, are likely to elicit negative emotional reactions, for they involve a clash of interests and possible links to militarized conflict. As tensions recede, emotions may subside as well, but the latter will leave behind their traces. As the neuroscientist Damasio has noted, previous affective reactions can leave behind "somatic markers," or in other words feelings associated with certain stimuli. ${ }^{31}$ Negative emotional experiences can leave behind a propensity for negative feelings toward the actors associated with their cause. Repeated tensions will reinforce these feelings. As negative episodes accumulate actors may become ever more likely to overreact to possible provocations and slights as the threshold for evoking such feelings becomes successively lower.

What is more, such feelings are also important for their influence on how we interpret the world. Mercer, in particular, examined the implications of this dynamic in his work on emotional beliefs. Mercer writes, "an emotional belief is one where emotion constitutes or strengthens a belief and which makes possible a generalization about an actor that involves certainty beyond evidence." 32 Put differently, emotional beliefs involve felt reactions providing evidence where evidence is otherwise lacking. The evidence may all point towards one conclusion, but we still may not believe it because our feelings tell us otherwise. As two psychologists note, "interventions attempting to change feelings by encouraging [an individual] to 'know better' or 'know more' may not always work in the long run, because 'feeling it'... refers to a qualitatively distinct meaning level."

In sum, iterated and unresolved episodes of tension can solidify hostile images according to which future interactions are interpreted. The more hostile the image, the more difficult it is to dislodge, for actors will view even an ambiguous or conciliatory gesture suspiciously. The emotions experienced during tensions can further buttress this effect by

${ }^{30} \mathrm{Maoz}$ and Mor, Bound by Struggle: The Strategic Evolution of Enduring International Rivalries.

${ }^{31}$ Damasio, Descartes' Error: Emotion, Reason, and the Human Brain (New York: G. P. Putnam, 1994).

32 Mercer, "Emotional Beliefs," 2.

33 Samoilov and Goldfried, "Role of Emotion in Cognitive-Behavior Therapy," Clinical

Psychology: Science and Practice 7, no. 4 (2000). 
leaving behind negative feelings towards the other party. These feelings not only can trigger stronger reactions in the future, they also can act to further solidify hostile beliefs.

It is further important to note that changing balances of power can aggravate this effect, for the actor on the declining side of the balance already has to fear the possibility that its counterpart will take advantage of its growing relative strength. This anxiety can create a context in which the behavior of the rising actor is closely watched for any sign of revisionist tendencies, and previously innocuous disputes come to be treated as harbingers of greater conflicts to come. With such worries in place, the effects of iterated yet unresolved episodes of tension can take on ever greater salience.

2) Iterated, unresolved episodes of tension can lead to a hardening of positions and willingness to resort to coercive or violent behavior.

Leng, in his analysis of multiple crises, noted that successive crises are likely to cause leaders to adopt more coercive positions in the future: "A militarily victorious state would see no reason for accommodation in the next crises... But the battlefield loser also is likely to become more determined to demonstrate its resolve through a tougher bargaining strategy so that the previously victorious adversary will not conclude that it can be bullied." 34 The logic is simple. The winner seeks to repeat the last win; the loser sees itself as needing to stand firmer in the next round. With each iteration, the level of coercive threat - if not outright use of military force - is ramped up. Conversely, the willingness to make concessions or compromise decreases.

This is exacerbated by well-known cognitive biases. ${ }^{35}$ The first is general tendency towards a willingness to engage in riskier behavior when an actor perceives itself to be acting in a domain of losses. More precisely, when an actor perceives itself having lost something in the past - be it status, territory, or any other value - it may become more inclined to take greater risks in the future. In the context of iterated, unresolved episodes of tension there is in each iteration likely to be one participant - if not both - who will see themselves as having suffered some form of loss. This means that going into the next round, they may be more willing to take risks to regain or preserve their position.

What is more, there is the danger of the bias towards positive illusions. ${ }^{36}$ Actors frequently overestimate their abilities and engage in unrealistic optimism. It is a well-known statistic that the majority of drivers rate their skills as above average - a mathematical impossibility. ${ }^{37}$ Unfortunately, such gross overestimates of ability are not limited to the

${ }^{34}$ Leng, "When Will They Ever Learn? Coercive Bargaining in Recurrent Crises," 384. Lebow comes to a similar conclusion: Lebow, Between Peace and War: The Nature of International Crisis, 316.

${ }^{35}$ Kahneman and Renshon, "Why Hawks Win," Foreign policy (2007); McDermott, Political Psychology in International Relations (Ann Arbor: University of Michigan Press, 2004). 36 Kahneman and Renshon, "5 Hawkish Biases," in American Foreign Policy and the Politics of Fear: Threat Inflation since 9/11, ed. Thrall and Cramer (Routledge: Abingdon, 2009). 37 Svenson, "Are We All Less Risky and More Skillful Than Our Fellow Drivers?," Acta Psychologica 47, no. 2 (1981). 
realm of driving. Kahneman and Renshon note, "The consequences of positive illusions are overwhelmingly harmful... Positive illusions generally favor hawkish, aggressive behavior when conflict exists or when a side already contemplates hostile actions." 38 As iterated, unresolved tensions persist and actors shift towards more coercive policies, the likelihood is that they will also overestimate their ability to succeed should conflict emerge. This increases the chances that they will be willing to run the risk of war.

Finally, there is the emotional component. Where actors see themselves as having been slighted in previous confrontations, this can generate feelings of humiliation and the desire for revenge. Indeed, humiliation and revenge are closely linked, for "by enacting revenge, the victim reenacts the humiliation in reverse and transforms its experience from passive to active... revenge relieves the emotional suffering caused by humiliation."39 Numerous scholars have noted the role of revenge in motivating violent behavior in international relations. ${ }^{40}$ Iterated, unresolved episodes of tension can leave the perceived losers in a state of humiliation, such that the next round offers the chance for revenge. This, in turn, increases the attractiveness of hardline measures - both to forestall further humiliations and exact punishment on the other party.

In total, the effects of iterated, unresolved episodes of tension can cumulate in a gradual shift towards hawkish behavior by both sides. There are reasons for this to be found in the effects of learning, cognitive biases, and emotional reactions. We can see manifestations of this not only in behavior during subsequent episodes of tensions, but also in the interim, as actors move to acquire military capabilities to better equip themselves for coercive action or tie themselves closer to allies. As capabilities and support from allies increase, so too does the confidence that coercion will succeed, even further intensifying the dangers involved.

3) Iterated, unresolved episodes of tension can have indirect effects in shaping public attitudes, leading to pressure for more hawkish policies.

The effects of iterated, unresolved episodes of tension on beliefs, attitudes, and emotions can work both directly, by shaping the choices and behavior of key decision-makers, or indirectly, by influencing the domestic political climate within which they operate. The direct effects are quite simple to elaborate. With each crisis or new incident, policymakers' attitudes harden and these become reflected in the choices they adapt. As work on the role of individuals in international relations has emphasized, periods of tension or crisis are situations where individual-level factors are most likely to play a role. ${ }^{41}$

38 Kahneman and Renshon, "5 Hawkish Biases," 82.

${ }^{39}$ Löwenheim and Heimann, "Revenge in International Politics," 696-97.

${ }^{40}$ Lebow, Why Nations Fight: Past and Future Motives for War (Cambridge University Press, 2010), 185-88; Löwenheim and Heimann, "Revenge in International Politics."; Saurette, "You Dissin Me? Humiliation and Post 9/11 Global Politics."

${ }^{41}$ Byman and Pollack, "Let Us Now Praise Great Men," International Security 25, no. 4 (2001). 
But policymakers also exist within a domestic context that can shape their behavior in future conflicts. All the effects listed above can work more broadly on the public level as well, also shaping attitudes of a leader's domestic constituents towards perceived foreign antagonists. As public attitudes (or the attitudes of a more limited selectorate on whom leaders' positions may depend) worsen with each iterated episode of tensions, this too can exert important effects. ${ }^{42}$ The first is selection effects. That is, publics - particularly in states with elected leaders - may gravitate towards and promote leaders that appear to take a more hawkish stance, while marginalizing more dovish leaders. Second, even if leaders do not find themselves replaced, they still may experience the constraining effects of public opinion. In other words, leaders may see themselves as needing to pursue a more hawkish policy to pacify public opinion or opposition within their own government. Finally, already hawkish leaders will be unshackled - given the freedom to pursue more confrontational policies with the blessing of their domestic constituents. Regardless of which set of effects one witnesses, the result is the same: a more hawkish turn.

That said, it is important to note the flipside of these dynamics: namely, these above effects can conceivably be mediated by leadership change due to exogenous causes. Indeed, the selection of leaders is rarely based on a single foreign policy stance. Leadership change on the basis of factors unrelated to the tensions in question (i.e. domestic policy or a coup) can under certain circumstances bring to power an actor unscarred by previous interactions and thus more predisposed towards a conciliatory stance. To the extent that the political factors behind this leadership change are sustainably dominant, they may also counterbalance or overshadow the effects of accumulated public attitudes. Furthermore, the presence of a new actor (or actors) at the helm of one state may also conceivably lead erstwhile rivals to re-evaluate possibilities for reconciliation or at least focus energies elsewhere. This phenomenon is most likely where we see a relatively radical change in leadership. The new attitude towards Russia held by (at the time of this writing) U.S. President-elect Donald Trump offers one possible example of this dynamic. Short-circuiting the cycle is thus possible, but it does require a major break in the leadership of at least one of the actors. What is more, maintaining such a course change may not be easy, especially when it faces ongoing indirect effects in the form of elite and public skepticism.

\section{Historical Precedent}

To sum up, iterated, unresolved episodes of tension set the stage for the further deterioration of relations between actors and raise the risk of future conflict. Tensions may subside, but when unresolved they leave behind the seeds of future trouble. And as noted in the introduction, there is historical precedent that suggests the above is not simply speculation: the outbreak of World War I. ${ }^{43}$ Specifically, World War I came in the

${ }^{42}$ Lebow, Between Peace and War: The Nature of International Crisis, 316-17; Vasquez, The War Puzzle Revisited, 110, 216-44.

${ }^{43}$ Ja Ian Chong and Todd Hall. 2014. "The Lessons of 1914 for East Asia Today,"

International Security, 39(1): See also: Lebow, Between Peace and War: The Nature of

International Crisis, 310-17; Arthur Stein, "Respites or Resolutions? Recurring Crises and the

Origins of War," in The Next Great War? , ed. Miller (Cambrige: MIT Press, 2015): 13-25. 
wake of a series of episodes of tension that had set the stage for its appearance. These include the First and Second Moroccan crises of 1905-06 and 1911, the Bosnian Crisis of 1908-09, the Balkan Wars in 1912 and 1913, as well as the domestic turmoil in Russia following defeat in the 1904-05 Russo-Japanese War. ${ }^{44}$ With each crisis, the actors involved saw their counterparts with more distrust, and were evermore likely to interpret behavior in negative terms. Indeed, as increasing antipathy fueled mistrust and hypersensitivity, even minor events - such as the appointment of a German to reform the Ottoman army (the Liman Affair) ${ }^{45}$ or the treatment of German deserters of French Foreign Legion (the Casablanca Incident) ${ }^{46}$ - led to belligerent threats. As grievances accumulated, the system grew more volatile.

Concurrently, actors saw the need to be more hawkish in the next confrontation. A key example of this is the Bosnian crisis, which emerged when Austria-Hungary annexed the formerly Ottoman provinces of Bosnia-Herzegovina. Russia and Serbia immediately objected to the Austrian move, and war seemed a possibility as all sides mobilized their forces. But Russia and Serbia eventually backed down when Germany threatened to support Austria-Hungary in case of open hostilities. From this Austria-Hungary and Germany took the lesson that belligerent threats could force Russia into retreat. As the Austrian foreign minister, Alois Aehrenthal, noted, "[A] text-book (Schulbeispiel) example of how success is only certain if the strength (Kraft) is there to get one's way."47 But for Russia the experience "was a humiliation, the like of which Russia must never again be made to endure." 48 Russia subsequently sought to increase its military strength to avoid a similar disgrace in the future.

And the effects were both direct and indirect. The direct effects can be seen in the Kaiser's comments prior to World War I after having suffered two humiliations in previous crises: "This time I shall not given in." 49 The indirect effects were also visible. As Lebow writes, "Shifts of power [towards hawks] occurred in Russia and France in the

${ }^{44}$ David Stevenson, "Militarization and Diplomacy in Europe before 1914," International Security, Vol. 22, No. 1 (Summer 1997), pp. 125-161.

${ }^{45}$ Sean McMeekin, The Russian Origins of the First World War (Cambridge: Harvard University Press, 2011), pp. 30-33.

${ }^{46}$ Michael E. Nolan, The Inverted Mirror: Mythologizing the Enemy in France and Germany, 1898-1914 (Oxford: Berghahn, 2005), pp. 14-15. See also: MacMillan, The War That Ended Peace, p. 400.

47 Politisches Archiv XII/357, Aerhrenthal to Wekerle, March 31, 1909, as quoted in F. R. Bridge, The Hapsburg Monarchy Among the Great Powers, 1815-1918 (Oxford: Berg, 1990), p. 295. See also Margaret MacMillan, The War That Ended Peace (London: Profile Books, 2013), p. 407.

${ }^{48}$ Clark, The Sleepwalkers, p. 259.

${ }^{49}$ Fritz Fischer, War of Illusions: Germany Policies from 1911 to 1914, (London: Chatto and Windus, 1975), p. 478; see also Clark, The Sleepwalkers: How Europe Went to War in 1914 (HarperCollins, 2013), 522.; and MacMillan, The War That Ended Peace (London: Profile Books, 2013), 529. 
aftermath of the Bosnian and Agadir crises... Morocco and Bosnia also enhanced the influence of hardliners within the British Foreign Office." 50

All this help pushed Europe to the brink of war a century ago. ${ }^{51}$ Iterated unresolved tensions do leave behind effects, and those effects can be quite pernicious. The key question, consequently, is to what extent are such dynamics unfolding in East Asia today?

\section{Repeated Episodes of Tension in East Asia}

The above constitutes theoretical conjecture, albeit one supported by historical precedent, and we believe this to be directly relevant to iterated, unresolved episodes of tension between the PRC and its neighbors over longstanding maritime territorial disputes. To be clear, ours is not a mechanistic argument - we do not claim that these dynamics must develop wherever a territorial dispute arises. Rather our claim is that the tendencies we outline above can exacerbate the volatility of such disputes when they involve iterated, unresolved tensions. In what follows, we explore how the dynamics we describe can help illuminate recent developments in PRC-Japan and PRC-Philippines relations.

\section{PRG-Japan}

How do we explain the seeming instability of PRC-Japan relations? Following a round of anti-Japanese protests in the PRC in 2005, relations between Tokyo and Beijing actually seemed to be stabilizing after Abe Shinzō replaced Koizumi Junichirō in 2006. Having ended direct meetings with Koizumi over his repeated visits to the controversial Yasukuni Shrine, the change in leadership seemed to offer the PRC a new interlocutor with whom it could pursue improved relations. But a series of tensions surrounding the PRCJapanese dispute over the Diaoyu/Senkaku islands and East China Sea (ECS) subsequently appear to have hardened positions on both sides, permitting if not encouraging more provocative behavior while reducing the scope for dialogue.

Setting the context of recent PRC-Japanese tensions is the fact that PRC naval operations in the ECS have been increasing in frequency and sophistication since 2004, reflecting the growing capabilities of the People's Liberation Army Navy (PLAN). ${ }^{52}$ Many of these activities occurred in waters claimed by both Japan and the PRC, but where the PLAN was previously less able to operate. At the same time, PRC official and research vessels also had begun entering disputed waters with increasing frequency. ${ }^{53}$ In May 2009,

${ }^{50}$ Lebow, Between Peace and War: The Nature of International Crisis, 316.

${ }^{51} \mathrm{Maoz}$ and Mor, Bound by Struggle: The Strategic Evolution of Enduring International Rivalries; Vasquez, The War Puzzle Revisited, 110; Hensel, "An Evolutionary Approach to the Study of Interstate Rivalry."

${ }^{52}$ Michael Swaine and Taylor Fravel, "China's Assertive Behavior-Part Two: The Maritime

Periphery," China Leadership Monitor 35 (2011): pp. 7-9.

53 海上保安庁「中国公船等による尖閣諸島周辺の接続水域内入域及び領海侵入隻数（月 別）」, June 30, 2014, http://www.kaiho.mlit.go.jp/senkaku/index.html, accessed July 20, 2014, Yuki Tatsumi, "Senkaku Islands/East China Sea Disputes-A Japanese Perspective," in Michael 
Beijing submitted a note verbale on its ECS claims in response to a request by the United Nations Commission on the Limits of the Continental Shelf. ${ }^{4}$ These developments came amid efforts by Beijing and Tokyo to contain maritime disputes, including a 2008 joint exploration agreement in the ECS and attempts to prevent activists from landing on the disputed Diaoyu/Senkaku islands. ${ }^{55}$

Tensions broke into the open in 2010 when the Japanese Coast Guard (JCG) arrested the captain of a Chinese fishing trawler who used his vessel to ram JCG vessels in disputed waters near the Diaoyu/Senkaku Islands. The Japanese government contemplated charging the captain under domestic Japanese law, a move that the PRC government saw as tantamount to an exercise of Japanese sovereignty over the disputed waters in which the arrest occurred. ${ }^{56}$ The PRG consequently further increased the frequency and aggressiveness of patrols by paramilitary forces in the disputed waters and permitted a number of anti-Japanese protests in China. ${ }^{57}$ When the Japanese government decided to give in and release the Chinese captain, the PRC demanded an official apology and damages from Tokyo. ${ }^{58}$ This in turn prompted Tokyo to counter-demand an apology from the PRC and payment for damage caused to JCG vessels by the Chinese trawler. ${ }^{59}$ From the PRC perspective, Japan had unilaterally deviated from the prior practice of immediately repatriating Chinese fishermen taken into its custody and was increasing its legal claims to authority over the disputed islands; from the Japanese perspective, the $\mathrm{PRC}$ was acting in an "excessive" fashion. ${ }^{60}$

Absent a clear resolution to Sino-Japanese differences over the trawler incident, the PRC continued with intensified patrols of disputed waters by government vessels while the JCG responded by trying to actively chase these ships away. ${ }^{61}$ Among the incidents that occurred were purported instances of PRG helicopters and aircraft "buzzing" Japanese

McDevitt and Catherine Lea (eds.), CNA Maritime Asia Project Workshop Three:Japan's

Maritime Disputes (Arlington, VA: Center for Naval Analyses, 2013), pp.113-115.

${ }^{54}$ China, "Preliminary Information."

55 Tatsumi, "Senkaku Islands/East China Sea Disputes."

56 "Japan's PM rejects China's Demand for Apology," CNN, September 26, 2010, http://edition.cnn.com/2010/WORLD/asiapcf/09/26/china.japan.apology/, accessed July 19, 2014.

57 Tania Brannigan, "China Cuts Japan Contacts over Detained Trawler Captain," The Guardian, September 19, 2009, http://www.theguardian.com/world/2010/sep/19/chinajapan-contacts-detained-trawler-captain, accessed July 19, 2014, Martin Fackler and Ian Johnson, "Arrest in Disputed Seas Riles China and Japan," New York Times, September 21, 2010: A1, Swaine and Fravel, "China's Assertive Behavior," p. 8.

58 "Japan's PM rejects China's Demand for Apology."

${ }^{59}$ Zhao Yanrong, "Beijing Demands Apology for 2010 Boat-Ramming Incident," China Daily, February 13, 2014, http://www.chinadaily.com.cn/world/2014-02/13/content_17279981.htm, July 18, 2014.

${ }^{60}$ Michael Yahuda, Sino-Japanese Relations After the Cold War (New York: Routledge, 2014), p. 119.

${ }^{61}$ For Japan Coast Guard information on perceived PRC incursions into disputed waters between 2008 and June 2014, see: http://www.kaiho.mlit.go.jp/senkaku/index.html. 
ships and aircraft at very close, perhaps unsafe, distances ${ }^{62}$ Both the Japanese and PRC governments publicly complained about alleged infractions by the other side. ${ }^{63}$ Neither side was willing to back down and appear "softer" than the other.

As a consequence, in the subsequent period voices on both sides were advocating for less accommodative stances. In mid-2012, the highly nationalistic Tokyo governor, Shintaro Ishihara, announced his intention for Metropolitan Tokyo to buy the islands from their private owner, construct installations, station personnel, and conduct geological surveys. ${ }^{64}$ Japan's Noda government felt that such moves could prove overly provocative to the $\mathrm{PRC}$, and responded with a plan to purchase and nationalize the islands. They believed the approach was an acceptable compromise for both Beijing and the Japanese public. ${ }^{65}$ Taking a cool Chinese reception following communication of plan to the PRC Embassy in Tokyo as a signal of Beijing's tacit approval, the Japanese government publicly announced its plans. ${ }^{66}$ This move sparked not only strong official criticism from the PRC, but also intensified PRC air and sea patrols around the disputed islands as well as protests around China. ${ }^{67}$

Japan's official response was to scramble its own ships and aircraft to intercept PRC ones heading to patrol near or over the Diaoyu/Senkakus. This occurred despite a subsequent realization in Japanese policy circles that communicating through the Foreign Ministry by way of the embassy in Tokyo may have muddied the message sent to Beijing. ${ }^{68}$ These events corresponded with a spike in PRC ships and aircraft sent to the disputed area in

62 Roland Buerk, "Japan Protest over 'Dangerous" China Helicopter Fly-by," BBC Neres, March 8, 2011, http://www.bbc.com/news/world-asia-pacific-12674014, accessed July 19, 2014, "2 Chinese Fighter Jets Buzz Japanese Defense Force Aircraft," Channel News Asia, June 12, 2014, http://news.asiaone.com/news/asia/2-chinese-fighter-jets-buzz-japan-defense-forceaircraft, accessed July 18, 2014. Information detailing intercepts of PRC aircraft by the Japan Air Self-Defense Force available at: http://www.mod.go.jp/js/Press/press2014/press_pdf/p20140409.pdf.

${ }^{63}$ Swaine and Fravel, "China's Assertive Behavior," pp. 7-10. ${ }^{64}$ Jun Hongo, ““Tokyo's Intentions for Senkaku Islets,” Japan Times, April 19, 2012, http://www.japantimes.co.jp/news/2012/04/19/national/tokyos-intentions-for-senkakuislets/\#.U8y liFbSZ9Q accessed July 18, 2014, "Ishihara Seeking to Buy Senkaku Islands,"

Japan Times, April 18, 2012, http://www.japantimes.co.jp/news/2012/04/18/national/ishihara-seeking-to-buy-senkakuislands/\#.U8ylg1bSZ9Q accessed July 18, 2014, interviews with serving and former Japanese defense and foreign policy officials responsible for relations with the PRC during the nationalization of the Diaoyu/Senkaku Islands.

65 "Noda Government to Buy Senkaku Islands for 2 Billion Yen," Asahi Shimbun, September 5, 2012, http://ajw.asahi.com/article/special/isles_dispute/AJ201209050013, accessed July 18, 2014. Interviews with serving and former Japanese defense as well as foreign ministry officials responsible for maritime security and liaison with the PRC at the time of the Senkaku/Diaoyu nationalization.

66 Interviews with current and former Japanese officials.

67 海上保安庁「中国公船等による尖閣諸島周辺の接続水域内人域及び領海侵入隻数（月 別）」, Tatsumi, “Senkaku Islands/East China Sea Disputes," pp.113-115.

68 Interviews with current and former Japanese officials. 
2013, which, according to one senior PRG foreign ministry advisor, aimed to challenge effective Japanese administrative control ${ }^{69}$ In late 2013, China further announced the establishment of an ECS ADIZ that covered areas disputed with Japan, including the Senkaku/Diaoyu islands. ${ }^{70}$ PRC ADIZ regulations called for aircraft traversing the area to provide prior notification or face possible interception, going beyond common ADIZ practice requiring only that aircraft heading toward a state's territory provide such notification.

The handshake shared by Abe and PRC President Xi Jinping on the sides of the APEC meeting in late 2014 may have been hailed as an opening to ease tensions, ${ }^{71}$ but the situation remained tense. Periodic stand-offs, intercepts, and fire control radar lock-ons between PRG and Japanese aircraft and vessels, some of them heavily armed, continued to occur over the air and waters that Tokyo and Beijing dispute. ${ }^{72}$ Attempts to intercept PRG government aircraft by the Japan Air Self-Defense Force (JASDF) in 2014 matched that of scrambles against Soviet military aircraft during the height of the Cold War and have only increased. ${ }^{73}$ There were also increased Japanese troop and naval deployments near the Diaoyu/Senkaku, while areas near Japanese airspace and waters saw more frequent passage by PRC naval vessels and military aircraft as they transited to the Pacific for maneuvers. ${ }^{74}$ Most recently, Japanese and PRC officials have exchanged accusations of dangerous behavior by each other's fighters in the East China Sea. ${ }^{75}$

69 曲星「中國外交的頂尖設計與底線思維」《參考消息》, September 16, 2013, http://ihl.cankaoxiaoxi.com/2013/0916/272722.shtml, accessed July 18, 2014, 海上保安庁 $\ulcorner$ 中国公船等による尖閣諸島周辺の接続水域内入域及び領海侵入隻数（月別）」， Tatsumi, "Senkaku Islands/East China Sea Disputes," pp.113-115, author's interviews with current and former Japanese defense as well as foreign policy officials.

70 李宣良、王經國「中國宣布劃設東海防空識別區」《人民日報》, November 24, 2013, http://paper.people.com.cn/rmrb/html/2013-11/24/nw.D110000renmrb_20131124_7-01.htm, accessed July 18, 2014，「中國空軍在我東海防空識別區首次巡邏」中華人民共和國中央政 府, November 23, 2013, http://www.gov.cn/jrzg/2013-11/23/content_2533284.htm, accessed July 18, 2014.

${ }^{71}$ Yuki Hayashi, "Chinese President Xi, Japan PM Abe Meet in Beijing With Chilly Handshake," Wall Street Journal, November 10, 2014, http://www.wsj.com/articles/chinese-president-xijapan-pm-abe-meet-in-beijing-1415592213, accessed July 8, 2016.

${ }_{72}$ For a full listing of relevant incidents, see James Przystup, "Japan-China," in Comparative Connections, CSIS, Volumes 17-18. https://www.csis.org/programs/pacific-forumcsis/publications/comparative-connections, accessed December 8, 2016.

${ }_{73}$ Ankit Panda, "Japan Scrambles Jets as China Air Force Flies Bombers, Fighters through Miyako Strait," The Diplomat, November 27, 2016, http://thediplomat.com/2016/11/japanscrambles-jets-as-china-air-force-flies-bombers-fighters-through-miyako-strait/, accessed December 7, 2016, "China's Activities Surrounding Japan's Airspace," Ministry of Defense, Japan, http://www.mod.go.jp/e/d_act/ryouku/, accessed January 20, 2016, "Japan Jet Scrambles 'Near Cold War Record,"' BBC Nezes, April 16, 2015, http://www.bbc.com/news/world-asia-32330096, accessed January 20, 2016.

${ }_{74}$ International Crisis Group, East China Sea: Preventing Clashes from Becoming Crises, Asia Report No 280, June 30 2016, http://www.crisisgroup.org/en/regions/asia/north-east- 


\section{Repeating Tensions, Deepening Trouble}

In the situations outlined above we can observe how iterated episodes of tension led to both deepening suspicion and a hardening of positions. The Japanese side, by releasing the fishing captain in 2010 and, subsequently, seeking to prevent the nationalistic mayor of Tokyo, Ishihara, from purchasing the Diaoyu/Senkaku Islands in 2012 saw itself as acting in a conciliatory manner. It thus increasingly viewed the PRC responses as being paranoid over-reactions at best, intentionally duplicitous at worst. From the official PRC perspective, Japan was progressively and unilaterally moving to alter the status quo with the expectation that the PRG stand silent. Consequently, both sides hardened their positions. The PRC has increased its presence around the islands and moved forward with investment in relevant military and paramilitary capabilities. Japan, too, increased its military capabilities and loosened the legal restrictions on responding with force should a contingency arise. On top of this, it has sought to draw closer to the United States, which in return stated that it views the Diaoyu/Senkaku Islands as falling under the purview of its security treaty with Japan. ${ }^{76}$

These repeated and unresolved crises between Japan and the PRC have further resulted in the indirect effect of fanning mutual aversion - if not animosity - among the public on both sides. A China Daily-Genron NPO poll conducted in June and July 2013 found that $98.2 \%$ of Chinese polled and $90.1 \%$ of Japanese held negative views toward each other's countries. ${ }^{77}$ This represented an increase of 28\% in China and 5.8\% in Japan from 2012, with $77.6 \%$ of Chinese and $53 \%$ of Japanese citing continuing differences over the Diaoyu/Senkaku as the main reason for their unhappiness. These effects continue: 2015 Pew surveys still show approximately 88\% of the public in China and $91 \%$ in Japan having non-favorable opinions of each other's countries. ${ }^{78}$

asia/china/280-east-china-sea-preventing-clashes-from-becoming-crises.aspx, accessed on July 8, 2016.; James Przystup, "Japan-China," in Comparative Connections, CSIS, Volumes 17-18. https://www.csis.org/programs/pacific-forum-csis/publications/comparative-connections, accessed December 8, 2016.

${ }^{75}$ Franz-Stefan Gady, "Chinese and Japanese Fighter Jets Come Close to Dogfight in East China Sea," The Diplomat, July 6, 2016, http://thediplomat.com/2016/07/chinese-and-japanesefighter-jets-come-close-to-dogfight-in-east-china-sea/, accessed July 8, 2016.

${ }_{76}$ Martin E Manyin, "Senkaku (Diaoyu/Diaoyutai) Islands Dispute: U.S. Treaty Obligations Senkaku (Diaoyu/Diaoyutai) Islands Dispute: U.S. Treaty Obligations," CRS Reports, September 25, 2012, http://fpc.state.gov/documents/organization/198821.pdf, accessed December 8, 2016; Mizuho Aoki, "Obama assures Abe on Senkakus," Japanese Times, April 24, 2014, http://www.japantimes.co.jp/news/2014/04/24/national/obama-tells-abe-securitytreaty-covers-senkakus/\#.WElEhXecZhE, accessed December 8, 2016.

77 "Bad Feelings between Chinese, Japanese Worst in a Decade: Poll," UPI, August 8, 2013, http://www.upi.com/Top_News/World-News/2013/08/08/Bad-feelings-between-ChineseJapanese-worst-\%20in-a-decade-poll/UPI-35351375978657/\#ixzz2tOzD3vDQ accessed July 23, 2014.

${ }^{78}$ Pew Research Center, "Asians' Views of Each Other," Pew Research Global Attitudes Project, September 2, 2015, http://www.pewglobal.org/2015/09/02/how-asia-pacific-publicssee-each-other-and-their-national-leaders/asia-heat-map/, accessed July 8, 2016. 
Such sentiments generate both political resources and pressures. It was probably little coincidence that Abe chose to visit the Yasukuni Shrine at a time when relations with the PRC were at a low point following repeated tensions. ${ }^{79}$ Concern over an assertive PRC was also used as a political resource as the Abe administration sought to pass security laws allowing for more room for collective self-defense. ${ }^{80}$ This move enabled Japan to legally offer military assistance to friendly countries in the event of a conflict and expectedly drew heavy official criticism from Beijing for its potential to threat to the PRC as well as regional stability. ${ }^{81}$ Importantly, as Abe's efforts encountered significant domestic opposition, the Japanese side decided to release new information about PRC activities and construction in the ECS, furthering playing to perceptions of tense relations. ${ }^{82}$ The net effect of the series of unresolved crises over the ECS and the Diaoyu/Senkaku is that neither the PRG nor Japanese governments are in positions to back down and instead face pressure to demonstrate resolve. The agreed statements the two sides released on the islands in 2014 notwithstanding, growing nationalism in China and the current $\mathrm{Xi}$ leadership's ongoing efforts to further consolidate authority likely means that Beijing may not be in a position to compromise, especially with Japan. ${ }^{83}$ A PRC leader seen to be "soft" on Japan in such circumstances is almost sure to face significant pressure from rivals with the Chinese Communist Party and the public alike. Current apprehensions toward China among the Japanese public means that they may punish politicians whose policies toward the PRC appear overly accommodating.

In the context of recent Sino-Japanese relations we can observe how one episode - the trawler collision in 2010 - led to both distrust and a hardening of positions that shaped escalatory behavior in another - the nationalization crisis of 2012. While these were major incidents, there has also been myriad variety of minor confrontations that contribute to these trends as well, ranging from encounters in the sea and air to bitter diplomatic exchanges. And these tensions have further spilled over into other areas,

\footnotetext{
${ }^{79}$ Interviews with Japanese politicians and defense as well as foreign policy officials.

$80 「$ 安倍内閣総理大臣記者会見」首相官邸, July 1, 2014, http://www.kantei.go.jp/jp/96_abe/statement/2014/0701kaiken.html, accessed July 18, 2014, "Press Conference by the Cabinet Chief Secretary," The Prime Minister of Japan and his Cabinet, July 1, 2014, http://japan.kantei.go.jp/tyoukanpress/201407/1_a.html, accessed July 18, 2014, interviews with Japanese politicians, current and former defense as well as foreign policy officials.

81「2014 年 7 月 1 日外交部發言人洪否主持例行記者會」中華人民共和國外交部, July 1, 2014, http://www.fmprc.gov.cn/mfa_chn/fyrbt_602243/jzhsl_602247/t1170302.shtml, accessed July 18, 2014.

${ }^{82}$ Isabel Reynolds and Maiko Takahashi, "Japan Releases Photos of Chinese Rigs in East China Sea," Bloomberg, July 22, 2015, https://www.bloomberg.com/news/articles/2015-0722/japan-releases-photos-of-chinese-rigs-in-disputed-east-china-sea, accessed December 8, 2016. ${ }^{83}$ Adam Liff, "Principles Without Consensus: Setting the Record Straight on the 2014 Sino-Japanese 'Agreement to Improve Bilateral Relations'," Working Paper, November 8, 2014. http://www.adamphailliff.com/documents/Liff2014_PrinciplesWithoutConsensus.pdf, accessed December 8, 2016.
} 
including interactions concerning the PRC's disputes in the South China Sea. ${ }^{84}$ Although the direct effects on leadership perceptions can at this point only be inferred given the lack of access to internal policy documents and deliberations, the indirect effects are registered quite clearly in the extremely low levels of mutual affinity and trust shown by both publics. The combined effects of these dynamics have disconcerting implications for future stability.

\section{PRC-Philippines}

The trajectory of Sino-Philippine relations since the late 2000s is also illustrative of the rising mutual suspicions, hardening of positions, increasingly coercive behavior, and growing domestic constraints on compromise resulting from repeated, unresolved tensions. Manila-Beijing relations were stable and improving throughout the 2000s, with growing economic exchanges and cooperation through the Association of South East Asian Nations (ASEAN). ${ }^{85}$ Differences over the ownership over parts of the South China Sea (SCS) that both sides claim seemed to be on the backburner, particularly after the 2002 ASEAN-China Declaration on the Conduct of Parties in the South China Sea (DOG). ${ }^{86}$ Then came a May 2009 deadline to submit claims to the UN Commission on the Limits of the Continental Shelf (UNCLCS). The Philippines and the PRG made submissions relating to their claims, as did two other disputants, Vietnam and Malaysia. ${ }^{87}$

Rounds of iterated tensions over competing maritime claims set off a series of increasingly strident attempts by the Philippines and the PRC to assert their claims over mutually contested land features and waters that involved growing coercion and demonstrations of resolve. Following the submission of claims, Beijing and Manila attempted to expel and arrest fishermen in disputed waters, which precipitated into standoffs over maritime

${ }^{84}$ James Przystup, "Japan-China: No Lack of Dialogue, Results -- TBD," in Comparative Connections, (18:2) September 2016, p. 108-110.

https://www.csis.org/programs/pacific-forum-csis/publications/comparative-connections, accessed December 8, 2016.

${ }^{85}$ John Lee, "The End of Smile Diplomacy?" The National Interest, September 23, 2010 , http://nationalinterest.org/commentary/the-end-smile-diplomacy-4122, accessed May 19, 2016. 86 ASEAN, "Declaration on the Conduct of Parties in the South China Sea," November 4, 2002, http://www.asean.org/?static_post=declaration-on-the-conduct-of-parties-in-the-south-chinasea-2, accessed May 12, 2016.

${ }^{87}$ Republic of the Philippines, "A Partial Submission of Data and Information on the Outer Limits of the Continental Shelf of the Republic of the Philippines Pursuant to Article 76 (8) of the United Nations Commission on the Law of the Sea," April 8, 2009, http://www.un.org/depts/los/clcs_new/submissions_files/phl22_09/phl_esummary.pdf, accessed July 18, 2014, China, "Preliminary Information", People's Republic of China, Note

Verbale to the Secretary General of the United Nations with regard to the joint submission made by Malaysia and Viet Nam to the Commission on the Limits of the Continental Shelf,

CML/17/2009, May 7, 2009, http://www.un.org/depts/los/clcs_new/submissions_files/mysvnm33_09/chn_2009re_mys_vn m_e.pdf, accessed July 18, 2014. 
features both governments claim. ${ }^{88}$ There were some accounts of Chinese ships trying to ram or shoot at Filipino vessels, while the Philippines attempted to conduct seismic surveys in the waters around Reed Bank to bolster its position vis-à-vis the PRC. Chinese ships harassed Filipino vessels trying to resupply an outpost on Second Thomas Shoal in early 2014 despite a late 2013 understanding with ASEAN on guidelines to implement the DOC. ${ }^{89}$ Consequently, Manila began to bolster and advertise its alliance relationship with the United States as well as develop security ties with U.S. allies Australia, Japan, and South Korea to demonstrate an ability and willingness to defend its claims. ${ }^{90}$ These efforts include the ongoing acquisition of military and paramilitary aircraft and ships from the U.S. and its Asia-Pacific allies. ${ }^{91}$

Tensions grew further when a Philippine Navy attempt to arrest Chinese fishermen around Scarborough Shoal in April 2012 resulted in a standoff with ships from the China Maritime Surveillance. ${ }^{92}$ Both sides saw the event as a provocation by the other and refused to back down. The United States subsequently brokered a deal to have both sides

${ }^{88}$ Ian Storey, "China and the Philippines: Implications of the Reed Bank Incident," China Brief, vol. 11, no. 8, May 6, 2011,

http://www.jamestown.org/single/?no_cache= $1 \&$ tx_ttnews $\% 5$ Btt_news $\% 5 \mathrm{D}=37902 \#$. U8z2XF bSZ9Q, accessed July 16, 2014.

89 Zachary Keck, "Second Thomas Shoal Tensions Intensify," The Diplomat, March 13, 2014, http://thediplomat.com/2014/03/second-thomas-shoal-tensions-intensify/, accessed July 14,

2014, "Full Text of ASEAN-China Joint Statement on 10th Anniversary of DOC on South China

Sea," Global Times, November, 20, 2012, http://www.globaltimes.cn/content/745396.shtml, accessed May 20, 2016.

90 Renato Cruz de Castro, "Balikatan Exercise Highlights Territorial Defense and Multilateral Approach," Asia Maritime Transparency Initiative, Center for Strategic and International Studies, April 20 2016, http://amti.csis.org/balikatan-exercise-highlights-territorial-defensemultilateral-approach/, accessed May 19, 2016; "U.S. Relations with the Philippines," Bureau of Asian and Pacific Affairs, U.S. Department of State, November 13, 2015, http://www.state.gov/r/pa/ei/bgn/2794.htm, accessed May 19, 2016.

${ }^{91}$ Jaime Laude, "Philippine Navy Gets Three More Landing Ships from Australia," The

Philippine Star, March 29, 2016,

http://www.philstar.com/headlines/2016/03/29/1567208/philippine-navy-gets-3-morelanding-ships-australia, accessed May 19, 2016; Seth Robson, "Philippine Military Gets 2 Ships, 10 Helicopters with More on the Way," Stars and Stripes, August 25, 2015, http://www.stripes.com/news/philippine-military-gets-2-ships-10-helicopters-with-more-on-theway-1.364494, accessed May 19, 2016; "Japanese Firm to Build Ten 40-Meter Vessels for Philippine Coast Guard-DOTG," Department of Transport and Communications, Republic of the Philippines,

http://www.dotc.gov.ph/index.php/2014-09-02-05-01-41/2014-09-03-06-43-32/123-japanesefirm-to-build-ten-40-meter-vessels-for-philippine-coast-guard-dotc, accessed May 19, 2016;

"Philippines to Lease Planes from Japan to Patrol Disputed Waters," Reuters, March 9, 2016, http://www.reuters.com/article/us-southchinasea-philippines-idUSKCN0WB0TL, accessed May 19, 2016.

92 "Standoff at Scarborough Shoal," Al Jazeera, August 3, 2012, http://www.aljazeera.com/programmes/101 east/2012/07/201273093650328417.html, accessed July 17, 2014. 
withdraw. ${ }^{93}$ The Philippines complied, but the PRC maintained its presence and kept Filipino vessels away, effectively asserting control over the feature. ${ }^{94}$ The incident was a precursor to subsequent large-scale PRG construction of artificial islands on and fortification of several maritime features it disputes with the Philippines beginning in 2014. ${ }^{95}$ Beijing now possesses extensively reclaimed and fortified features in the SCS.

Accompanying developments at sea were a hardening of diplomatic positions by Beijing and Manila following the 2012 Scarborough Shoal incident. The Philippines tried work to with Vietnam to raise concerns over the SCS disputes at the 2010 ASEAN Regional Forum meeting in Hanoi. This sparked a sharp rebuke from then-PRC Foreign Minister Yang Jiechi. ${ }^{96}$ Yang reportedly told representatives from ASEAN member states they had to accept the fact that they are "small countries" compared to the PRC. ${ }^{97}$ Following its Reed Bank seismic surveys, Manila submitted a note verbale over its claims on April 5, 2011, the PRC responded with its own on April 14.98 A subsequent PRC attempt to block the Philippines from inserting language about the SCS during the 2012 ASEAN Ministerial Meeting resulted in the grouping failing to deliver a joint statement for the first time. ${ }^{99}$

Manila consequently submitted a formal, unilateral request for the UN to establish an arbitral tribunal to determine the nature of maritime features in parts of the SCS it disputes with the PRC in 2013, to the latter's public displeasure. ${ }^{100}$ From the start, there

${ }^{93}$ Jane Perlez, "Philippines and China Ease Tensions in Rift at Sea," Nerw York Times, June 19, 2012, A6.

${ }^{94}$ Manuel Montago, "Year After Panatag Stand-off, Shoal Firmly Controlled by Chinese," GMA News, April 23, 2013, http://www.gmanetwork.com/news/story/305062/news/world/a-yearafter-panatag-stand-off-shoal-firmly-controlled-by-china, accessed July 17, 2014.

95 "Island Tracker," Asia Maritime Transparency Initiative, Gentre for Strategic and

International Studies, http://amti.csis.org/island-tracker/, accessed May 19, 2016.

96 Richard Weitz, "Why US Made Hanoi Move," The Diplomat, August 18, 2010, http://thediplomat.com/2010/08/why-us-made-hanoi-move/, accessed July 16, 2014, Interviews with ASEAN diplomats familiar with the incident.

97 Aileen S.P. Baviera, "China: Less Charm, More Offensive," 25 th Asia-Pacific Roundtable, Kuala Lumpur, Malaysia, May 30-June 1, 2011; interviews with ASEAN diplomats familiar with the incident.

${ }_{98}$ Republic of the Philippines, Note Verbale, 11-00494 No. 228, April 5, 2011, http://www.un.org/depts/los/clcs_new/submissions_files/mysvnm33_09/phl_re_chn_2011.pdf, accessed July 18, 2014, People's Republic of China, Note Verbale, GML/8/2011, April 14, 2011 ,

http://www.un.org/depts/los/clcs_new/submissions_files/mysvnm33_09/chn_2011_re_phl.pdf, accessed July 18, 2014.

${ }^{99}$ Ernest Z. Bower, "China Reveals Its Hand on ASEAN at Phnom Penh," Center for Strategic and International Studies, July 20, 2012, http://csis.org/publication/china-reveals-its-handasean-phnom-penh, accessed July 17, 2014, interviews with ASEAN diplomats familiar with the incident.

100 "Statement: The Secretary of Foreign Affairs on the UNCLOS Arbitral Proceedings against China, January 22, 2013," Official Gazette (Philippines), 
were reasonable expectations that the arbitral tribunal would bring at least some PRG claims into serious question. ${ }^{101}$ Rather than see the arbitration as a means to clarify disputes, PRC leaders saw the move as an affront and sought to discredit the process while pressuring ASEAN. The PRG even attempted to exclude references to the SCS in ASEAN settings contributed to the use of an ASEAN chair's statement in lieu of a more authoritative joint statement at the 2015 ASEAN Defense Minister Meeting-Plus. ${ }^{102}$ The tribunal ultimately established the claims disputants can make based on control over various maritime features and rejected the legal standing of the nine dashed-lines the PRC uses as the basis for its position. ${ }^{103}$

Associated with a hardening of positions and growing tendency toward coercive tools was rising mutual suspicion between the PRG and Filipino governments. President Aquino publicly alluded to PRC actions in the SCS in general and Scarborough Shoal in particular as being akin to the behavior of Hitler and Nazi Germany. ${ }^{104}$ The PRC, for its part, accused the Philippines of first acting provocatively in the dispute and drawing in actors that have no business in their bilateral dispute, and insists its deployments of military forces to the SCS is self-defense, not militarization. ${ }^{105}$ The PRC refused to participate in the arbitration process. PRC Foreign Minister Wang Yi even indicated that the PRG will not abide by any rulings, as Beijing sees the arbitration process and outcome as "off-key" and "fouled." 106

\section{Learning Not to Back Down}

Repeated tensions between Manila and Beijing over the SCS mobilized domestic nationalism in both countries, which made compromise increasingly difficult. Before the deadline for submissions to the UNCLOS in 2009, the Philippine Congress enacted an archipelagic baseline law in February 2009 to bolster the domestic legal basis for Filipino

http://www.gov.ph/2013/01/22/statement-the-secretary-of-foreign-affairs-on-the-unclosarbitral-proceedings-against-china-january-22-2013/, accessed July 17, 2014.

${ }^{101}$ Robert Beckman, "The UN Convention on the Law of the Sea and the Maritime Disputes in the South China Sea," American Journal of International Law, Vol. 107 No. 1. (January 2013): 142-63.

102 See Seng Tan, "The Media Got the 3rd ADMM-Plus Meeting Wrong," PacNet 38, December 1, 2015, https://www.csis.org/analysis/pacnet-82-media-got-3rd-admm-plus-wrong, accessed May 19, 2016.

103 "PCA Press Release: The South China Sea Arbitration (The Republic of the Philippines v. The People's Republic of China," Permanent Court of Arbitration, July 12, 2016, https://pcacpa.org/en/news/pca-press-release-the-south-china-sea-arbitration-the-republic-of-thephilippines-v-the-peoples-republic-of-china/, accessed December 5, 2016.

${ }^{104}$ Keith Bradsher, "Philippine Leader Sounds Alarm on China," New York Times, February 5, 2014, A4.

105 U.S. Department of State, "Press Availability with Chinese Foreign Minister Wang Yi," January 27, 2016, http://www.state.gov/secretary/remarks/2016/01/251708.htm, accessed January 27, 2016. $106\ulcorner$ 王毅談南海仲裁：走調, 變味, 中方恕不奉陪」中華人民共和國外交部, March 8, 2016, http://www.fmprc.gov.cn/web/zyxw/t1345907.shtml, accessed March 8, 2016. 
claims as a response to the UN request. ${ }^{107}$ The law committed Filipino administrations to abide by a stricter interpretation of claims. Five Filipino legislators visited Thitu Island near disputed waters in June 2011 to reassert claims despite the Aquino administration being lukewarm to the idea. ${ }^{108}$ Filipino fishermen engaged in shouting matches with Chinese Coast Guard vessels chasing them away from disputed waters and few qualms about expressing frustration to the press, which fanned further public displeasure toward China in the Philippines. ${ }^{109}$ Partially in response to public pressure, the Aquino administration began referring to the SCS officially as the "West Philippine Sea" in 2011 despite Chinese protests. ${ }^{110}$

On Beijing's part, the PRC's education system consistently reinforces the idea that the SCS is an "inalienable" part of the country since "ancient times," and that archaeological findings in those waters support this position. ${ }^{111}$ The PRC's state managed press similarly reiterates the central nature of the SCS to the Chinese nation, including the claim that those waters are a "core interest" tied to the PRC's territorial integrity on par with control over Hong Kong, Taiwan, Tibet, Xinjiang. ${ }^{112}$ Despite new Filipino President Rodrigo Duterte indicating a willingness to take a softer stance, PRC State Councilor Dai Bingguo initially excoriated Manila for provocation at a 2016 speech in Washington, DC, even insinuating possible use of force. ${ }^{113}$ This suggested initial Chinese suspicion toward Filipino motivations for reaching out. The public prominence of such nationalist claims limited the flexibility of PRG leaders in managing the SCS disputes, especially given the

${ }^{107}$ Republic of the Philippines, Congress of the Philippines, Fourteenth Congress, Regular Session, "Republic Act No. 9522, An Act to Amend Certain Provisions of Republic Act No. 3046 as Amended by Republic Act No. 5446, To Define the Archipelagic Baseline of the Philippines and for Other Purposes," March 10, 2009, http://www.lawphil.net/statutes/repacts/ra2009/ra_9522_2009.html, accessed July 18, 2014. 108 "China Protests Congressmen's Trip to Spratlys," The Philippine Star, July 19, 2011 , http://www.philstar.com/headlines/707473/china-protests-congressmens-trip-spratlys, accessed May 17, 2016.

${ }^{109}$ J.C. Gotinga, "Filipino Fishermen Still Banned from Scarborough Shoal," CNN, July 12, 2016, http://cnnphilippines.com/news/2016/07/15/scarborough-shoal-filipino-fishermenchinese-coast-guard.htmll, accessed December 5, 2016, "Filipino Fishermen Pin Hopes on UN Tribunal," The Inquirer, June 22, 2016, https://globalnation.inquirer.net/140371/filipino-fishermen-pin-hopes-on-un-tribunal, accessed December 5, 2016.

110 Tarra Quismondo, "South China Sea Renamed in the Philippines," AsiaOne, June 3, 2011 , http://news.asiaone.com/News/Latest\%2BNews/Asia/Story/A1Story201 10613-283772.html, accessed May 14, 2016.

111 高之國、賈兵兵《論南海九段線的歷史、地位和作用》北京 : 海洋出版社 2014.

112 任沁沁、王建華「中國核心利益不容易挑戰」《新華網》May 25, 2015 http://news.xinhuanet.com/world/2015-05/25/c_1115401978.htm, accessed May 19, 2016.

113 Frances Mangosing, "Territorial Defense a Top Priority for Duterte Administration," Inquirer, July 1, 2016, http://globalnation.inquirer.net/140592/territorial-defense-a-toppriority-of-duterte-administration, accessed July 8, 2016, Speech by Dai Bingguo at China-US Dialogue on South China Sea Between Chinese and US Think Tanks, July 5, 2016, PRC Ministry of Foreign Affairs, http://www.fmprc.gov.cn/mfa_eng/zxxx_662805/t1377747.shtml, accessed July 8, 2016. 
potential for nationalist backlash. ${ }^{114}$ Such dynamics become particularly acute when PRG leaders felt themselves under pressure from domestic economic and political changes or reforms.

A 2013 Sino-Filipino standoff over Scarborough Shoal sparked protests in the PRC and the Philippines as well as expatriate communities elsewhere, cyberattacks by both sides, mutual fishing bans, a Chinese boycott of Filipino fruit exports, and a suspension of Chinese tours to the Philippines. ${ }^{115}$ A July 2014 Pew poll reported that 58 percent of Filipinos polled have non-favorable views of the PRC, up from 48 percent in 2013 and 30 percent in 2002, while 58 percent of respondents in the Philippines saw the PRC a threat. ${ }^{116}$ Concurrently, 93 percent of Filipinos polled saw the continuing territorial disputes with the PRC as a major problem for their country, a 3 percent increase from the previous year. ${ }^{117}$ Non-favorable Filipino views of China dropped to 43 percent in 2015, but 91 percent of respondents remained concerned about a territorial conflict with China. ${ }^{118}$ Whatever the limitations of such polling, they indicate a wariness toward the PRC in the Philippines due the SCS dispute and constrain Manila's choices.

Consistent with a leader coming to office with completely different priorities, Duterte's domestic focus and rapprochement with Beijing eventually calmed Philippines-PRC relations. However, Duterte's soft stance on territorial disputes with China may foster a future backlash in the Philippines if underlying unhappiness festers. Outreach by Duterte, including an official visit to China, won praise from Beijing and promises for deals worth US $\$ 24$ billion. ${ }^{119}$ Yet, key Filipino elites remain skeptical about Duterte's China policy, notably including his mentor, former President Fidel Ramos, who stepped down as special envoy to China after three months in apparent protest. ${ }^{120}$ The degree that PRC

114 Yinan He, The Search for Reconciliation: Sino-Japanese and German-Polish Relations since World War II (Cambridge: Cambridge University Press, 2009), Chs. 6-7.

${ }^{115}$ Ely Ratner, "Learning the Lessons of Scarborough Reef," The National Interest, November 21, 2013, http://nationalinterest.org/commentary/learning-the-lessons-scarborough-reef-9442, accessed July 17, 2014.

116 Pew Research Center, "How Asians View Each Other," Global Attitudes and Trends, July 14, 2014, http://www.pewglobal.org/2014/07/14/chapter-4-how-asians-view-each-other/, accessed July 8, 2016, Pew Research Center, "Philippines Opinion of China," Global Indicators Database,

http://www.pewglobal.org/database/indicator/24/country/173/response/Unfavorable/, accessed December 5, 2016.

117 Pew Research Center, "How Asians View Each Other."

118 Pew Research Center, "How Asia-Pacific Publics See Each Other and Their National Leaders," Glbal Attitudes and Trends, September 2, 2015, http://www.pewglobal.org/2015/09/02/how-asia-pacific-publics-see-each-other-and-theirnational-leaders/, accessed December 5, 2016.

119 Andreo Calonzo and Ceclia Yap, "China Visit Helps Duterte Reap Funding Deals Worth \$24 Billion," Bloomberg, October 21, 2016, https://www.bloomberg.com/news/articles/2016-10-21/china-visit-helps-duterte-reap-fundingdeals-worth-24-billion, accessed December 5, 2016.

${ }^{120}$ Yuji Vincent Gonzales, "Fidel Ramos Quits as Special Envoy to China," Inquirer, October 31, 2016, https://globalnation.inquirer.net/148429/fidel-ramos-quits-as-special-envoy-to-china, 
promises materialize remains unclear, although an inability to deliver could fuel popular resentment. Moreover, Filipino access to disputed waters remains at Beijing's pleasure, Duterte has not compromised on territorial claims, and officials privately report no change in instructions on the handling of territorial disputes. ${ }^{121}$ These stress points can limit cooperation, re-ignite past unresolved, iterated Sino-Filipino differences, and cause even improving relations to quickly sour. Recall that the previous Aquino administration and the PRC's Hu Jintao leadership spent a year seeking cooperation before such efforts broke down into the contentiousness that characterized the remainder of Aquino's term. ${ }^{122}$

\section{Conclusion}

Though preliminary and wanting of greater detail, the cases above strongly suggest that unresolved, recurrent episodes of tensions can pave the way for further friction and increase the potential for escalation. Without some sort of mutually acceptable and recognized accommodation among disputants, publics may come to resent the prevailing status quo and push leaders to take an increasingly tough stance the next time a crisis erupts with the same actor. Leaders who expect little forgiveness from publics for backing down may seek ever-toughening positions or even take the risk of "gambling for resurrection" if a crisis is not turning out favorably. ${ }^{123}$

Unresolved, iterated tensions may be increasingly susceptible to escalation with each subsequent round, particularly as actors come increasingly see themselves in the domain of losses. ${ }^{124}$ All this suggests that dyads with unresolved, recurrent tensions may be

accessed December 5, 2016, Fidel V. Ramos, "DU30's First 100 Days - Team Philippines Losing," Manila Bulletin, October 22, 2016, http://news.mb.com.ph/2016/10/08/du30s-first100-days-team-philippines-losing/, accessed December 7, 2016, Paolo Romero, "Senators Want \$24-B Aid from China Reviewed," Philippine Star, October 24, 2016, http://www.philstar.com/headlines/2016/10/24/1636811/senators-want-24-b-aid-chinareviewed, accessed December 5, 2016.

${ }^{121}$ Camile Abadicio, "Filipino Fishermen Still Facing Challenges at Scarborough Shoal," $C N N$ Philippines, November 12, 2016, http://cnnphilippines.com/news/2016/11/12/Scarborough-Shoal-Filipino-fishermen.html, accessed December 5, 2016, Mangosing, "Territorial Defense a Top Priority for Duterte Administration."

122 "Chinese Ambassador to Philippines Meets with Aquino," Xinhua, May 27, 2010, http://news.xinhuanet.com/english2010/china/2010-05/27/c_13319541.htm, accessed December 5, 2016, Statement of President Aquino during the 13th ASEAN-China Summit, Hanoi, Vietnam, October 29, 2010, Official Gazette, http://www.gov.ph/2010/10/29/statement-of-president-aquino-during-the-13th-asean-chinasummit/, accessed December 5, 2010.

123 George W. Downs and David M. Rocke, "Conflict, Agency, and Gambling for Resurrection: The Principal-Agent Problem Goes to War," American Political Science Review, vol. 38 no. 2 (May 1994): pp. 362-80.

${ }^{124}$ Kahneman and Renshon, "5 Hawkish Biases," pp. 79-98, Jack S. Levy, "Prospect Theory and International Relations: Theoretical Applications and Analytical Problems," Political

Psychology, vol. 13 no. 2 (1992): pp. 283-310, Jack S. Levy, "Prospect Theory, Rational Choice, 
especially dangerous and prone to conflict. The progression from the Morocco Crises through the Balkans and, ultimately, World War I may be reflective of the escalatory potential of iterated tensions, although we do not expect such an extreme outcome in the East Asian context. ${ }^{125}$

Southeast Asia offers further examples of where the logic of repeated tensions bears out. Vietnam and the PRC experienced a series of escalating tensions over their dispute in the South China Sea starting around 2008. This included mutual arrests of fishermen and the impounding of their vessels leading to harassment of each other's oil exploration efforts. These events included intentional collision among ships and the reclamation of SCS features each controlled. ${ }^{126}$ That both sides stuck to demonstrating resolve contributed to increasingly forceful attempts to challenge each other, growing mutual suspicion, and domestic mobilization against the other on nationalist grounds, including violent antiChinese riots in Vietnam in 2014. ${ }^{127}$

Importantly, conscious Malaysian efforts to avoid friction with China enabled PutrajayaBeijing relations to be less fraught and more cooperative, including on military matters such as allowing Chinese naval access to Malaysian port facilities. ${ }^{128}$ This despite the fact that Chinese actions in SC.S waters disputed with Malaysia can appear provocative. ${ }^{129}$

and International Relations," International Studies Quarterly 41 (1997): pp. 87-112, Rose McDermott, Risk-Taking in International Politics: Prospect Theory in American Foreign Policy (Ann Arbor: University of Michigan Press, 1998), Ch. 2, George A. Quattrone and Amos Tversky, "Contrasting Rational and Psychological Analyses of Political Choice," American Political Science Review, vol. 82 no. 2 (September 1988): pp. 719-36.

${ }^{125}$ Ja Ian Chong and Todd Hall, "The Lessons of 1914 for East Asia Today," International Security, vol. 39 no. 1 (Summer 2014).

${ }^{126}$ Lincoln Feast and Greag Torode, "Exclusive: Risking Beijing's Ire, Vietnam Begins Dredging on South China Sea Reef," Reuters, December 9, 2016, http://www.reuters.com/article/ussouthchinasea-vietnam-idUSKBN13X0WD, accessed December 9, 2016, Greg Torode,

"Vietnam Builds Military Muscle to Face China," Reuters, December 18, 2015, http://www.reuters.com/article/us-vietnam-china-conflict-insight-idUSKBN0U000320151218, accessed May 19, 2016, "Vietnam Responds with Spratly Air Upgrades," Asia Maritime

Transparency Initiative, Center for Strategic and International Studies, December 1, 2016, https://amti.csis.org/vietnam-responds/, accessed December 7, 2016.

127 Eva Dou and Richard C. Paddock, "Behind Vietnam's Anti-China Riots, A Tinderbox of Wider Grievances," Wall Street Journal, June 17, 2014,

http://www.wsj.com/articles/behind-vietnams-anti-china-riots-a-tinderbox-of-wider-grievances1403058492, accessed May 19, 2016.

${ }_{128}$ Cheng-Chwee Kuik, "Making Sense of Malaysia's China Policy: Asymmetry, Proximity, and Elite's Domestic Authority," Chinese Journal of International Politics, vol. 6 no. 4 (April 12, 2013): pp. 429-67; "PLA Navy Gains Use of Port in Malaysia Close to Spratly Islands," South

China Morning Post, November 21, 2015, http://www.scmp.com/news/china/diplomacy-defence/article/1881300/pla-navy-gains-useport-malaysia, accessed May 19, 2016.

129 Prashanth Parameswaran, "Did China's Vessels Encroach Malaysia's Waters?" The

Diplomat, March 29, 2016, http://thediplomat.com/2016/03/did-china-vessels-encroach- 
Absent repeated tensions, Sino-Malaysian relations remained much calmer despite disputes paralleling those Beijing has with Hanoi, Manila, and Tokyo. Beijing's financial support for Malaysian sovereign wealth funds to cover for funds senior officials allegedly siphoned supposedly paved the way for further Sino-Malaysian cooperation, including over security and the SCS. ${ }^{130}$ This development could, however, lead to a popular backlash against the PRC given efforts by Malaysian politicians to mobilize inter-ethnic differences that target local ethnic Chinese and their perceived loyalty to the PRC. ${ }^{131}$

A key objective of this essay is to demonstrate the plausibility for repeated episodes of tension to feed inter-state friction, creating conditions conducive to escalation, miscalculation, and even conflict. The cases this essay examines demonstrate that there is reason to believe in the external validity of our reasoning, as well as the empirical significance of repeated episodes of tension for international politics. Having established instances where this dynamic may be playing out empirically, a next step is to develop more fine-grained hypothesis to test the mechanisms that give recurrent tensions their combustible quality and to evaluate them against more detailed evidence. Developments in this direction can include exploring the psychological effects and domestic political dynamics that result from recurring tensions on both leaders and publics that may encourage resolve rather than accommodation. How recurrent tensions play out under different regime types and institutional settings may also provide avenues for further study.

Going forward, understanding unresolved, repeated tensions and appreciating their consequences are especially important at moments of acute uncertainty. World politics is

malaysias-waters/, accessed May 19, 2016; 「高清：中國海巡 31 船出訪新加坡 巡航南海維護 主權」《人民網》June 16, 2011, http://thediplomat.com/2016/03/did-china-vessels-encroach-malaysias-waters/, accessed May 19, 2016.

${ }^{130}$ Jeevan Vasagar, Caroline Binham, and Simeon Kerr, "Chian to Help 1MDB to Settle Multibillion-Dollar Legal Dispute," Financial Times, Decemeber 7, 2016, https://www.ft.com/content/48689508-b6ae-11e6-ba85-95d1533d9a62, accessed December 7, 2016, "China and Malaysia Agree on Military Cooperation in the South China Sea," The Guardian, November 2, 2016, https://www.theguardian.com/world/2016/nov/02/china-and-malaysia-agree-on-militarycooperation-in-the-south-china-sea, accessed December 6, 2016, "Malaysian PM to Sign 'Significant' Defence Deal with China Amid U.S. Strains," The Guardian, November 1, 2016, https://www.theguardian.com/world/2016/nov/01/malaysia-najib-razak-defence-deal-chinabeijing-visit, accessed December 6, 2016, 林友順「中馬軍演新加坡坐立不安」《亞州週刊》 第 30 卷第 49 期 (December 11, 2016), http://www.yzzk.com/cfm/content_archive.cfm?id=1480564305072\&docissue=2016-49, accessed December 9, 2016.

${ }^{131}$ Kate Mayberry, "Colour-Coded Racial Tensions Grow with Malaysia Rallies," Al Jazeera, September 15, 2016, http://www.aljazeera.com/indepth/features/2015/09/colour-coded-racial-tensions-growmalaysia-rallies-150915100610235.html, accessed December 6, 2016, Joseph Sipalan, "Malaysia's Najib Risks Backlash at Home after Deals with China," Reuters, November 7, 2016, http://www.reuters.com/article/us-malaysia-china-idUSKBN1320EY, accessed December 6, 2016. 
arguably at just such a juncture with the PRC's increasingly strained relative rise, America's relative decline under a potentially unpredictable administration, and Europe's prolonged stasis. Washington and Beijing are likely to probe and test the other's resolve at the start of the Trump administration and as the Xi Jinping-led PRC leadership faces more economic and social pressure at home. Russia and Europe may similarly check and challenge each other as differences mount and internal stresses grow. These are contemporary instances where unresolved, repeated tensions may have special salience for international security.

Inadequately addressed, iterated tensions can allow differences to sharpen, crises to foment, and possibly even foster confrontation. A cursory glance suggests several more such relationships in Asia and beyond. In Asia, they include not only dyadic cases involving the PRC, Japan, the Philippines, Vietnam mentioned or discussed in detail, but also South Korea, North Korea, Taiwan, India, Pakistan, and, of course, the United States. Beyond Asia, there are the Russia-Europe, Russia-United States, and Israel-Iran dynamics to name a few. An improved ability to address and manage these sorts of tense relations may prove helpful in staving off unneeded friction and maybe even conflict during these unsettled times. 